
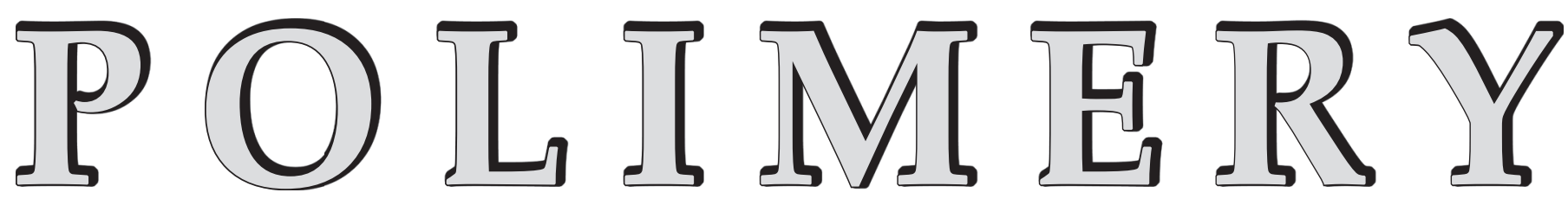

\title{
Bioresorbable polymeric materials - current state of knowledge
}

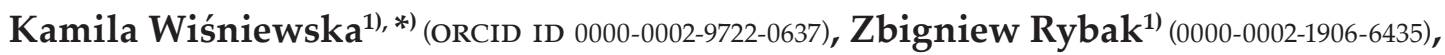 \\ Marcin Wątrobiński ${ }^{2)}$, Marcin H. Struszczyk ${ }^{3)}$ (0000-0002-1788-7862), Jarosław Filipiak ${ }^{4)}$ (0000-0002-9380-0642), \\ Bogusława Ży wicka ${ }^{1)}$ (0000 -0003-4307-9188), Maria Szymonowicz ${ }^{1)}$ (0000-0003-4251-6841)
}

DOI: dx.doi.org/10.14314/polimery.2021.1.1

\begin{abstract}
Bioresorbable materials are used in medicine for fixing, correcting or stabilizing bones in various anatomical areas, and the market for such materials is growing rapidly worldwide. The use of polymers for their production is associated with the ability to control their properties. They are prepared from bioresorbable materials with variable surface, geometry, porosity, as well as mechanical and surface properties. They support bone healing and are suitable for tissue regeneration due to their biodegradability and biocompatibility. We believe that materials from biodegradable polymers will play an increasingly important role in future medicine.
\end{abstract}

Keywords: poly(lactic acid) (PLA), biocompatible polymers, biocompatibility, biopolymers, bone graft implant.

\section{Bioresorbowalne materiały polimerowe - obecny stan wiedzy}

Streszczenie: Materiały bioresorbowalne są szeroko stosowane w medycynie do uzupełniania ubytków kości w różnych stanach chorobowych i powypadkowych, a także do nadbudowy i odbudowy kostnej oraz mocowania złamań. Rynek tego typu materiałów szybko się rozwija na całym świecie. Powszechność wykorzystania polimerów jest związana z możliwością kontrolowania ich właściwości. Zaletą materiałów polimerowych jest możliwość zmiany powierzchni, geometrii, porowatości, właściwości mechanicznych i powierzchniowych, a także ich biodegradowalność i biokompatybilność. Materiały z polimerów biodegradowalnych będą zapewne odgrywać coraz poważniejszą rolę w medycynie przyszłości.

Słowa kluczowe: poli(kwas mlekowy) (PLA), biokompatybilne polimery, biokompatybilność, biopolimery, implant kostny.

Guided bone regeneration using a resorbable or nonresorbable medical device has been shown to be effective in vitro and in vivo conditions. A resorbable mate- rial has the advantage of gradual bone substitution. For tissue engineering and guided bone regeneration resorbable components of $\alpha$-hydroxy acids (such as polylactide

\footnotetext{
1) Wroclaw Medical University, Department of Experimental Surgery and Biomaterials Research, Bujwida 44, 50-368 Wrocław, Poland.

2) Syntplant sp. z o.o., Rubież 46/4c, 61-612 Poznań, Poland.

3) Institute of Security Technologies "MORATEX”, Marii Skłodowskiej-Curie 3, 90-505 Łódź, Poland.

4) Wroclaw University of Science and Technology, Department of Mechanics, Materials and Biomedical Engineering, Ignacego Łukasiewicza 7/9, 50-371 Wrocław, Poland.

*) Author for correspondence: wisniewska.kami@gmail.com
} 
or polyglycolide) are widely used [1, 2]. The design of synthetic biomaterials for the bone fixations has significantly increased the effectiveness of orthopedic surgery. Over the years, several materials such as metals, ceramics, polymers and composites have been considered for possible implantation into the body with the advancements in medical technology. However, these materials should indicate properties necessary to qualify them as potential medical devices, which include biocompatibility, required mechanical properties, resistance against corrosion, resistance to creep, biomimetics behavior, porosity, density similar to the natural bone, etc. [3, 4]. Bioresorbable devices produced through melt extrusion, injection molding or compression molding only exhibit modest strength values and are usually brittle and flexible [5].

The bone is a complex and dynamic tissue that provides mechanical support for the body and exhibits the Young's modulus between 0.15-0.5 GPa for trabecular bone and 15-20 GPa for cortical bone. Metallic materials have used in the manufacturing of implants have significantly higher stiffness modulus values. The Young's modulus of $\mathrm{Ti}$ alloy $\left(\mathrm{Ti}_{6} \mathrm{Al}_{4} \mathrm{~V}\right)$ amounted to the values of approximately $115 \mathrm{GPa}$, stainless steel and chrome cobalt alloys 200-220 GPa [3, 6]. The discrepancy between bone and metallic implants in the elastic modulus is not beneficial for bone healing. For example, a fractured bone fixed with a stainless-steel implant that is not biodegradable has a tendency towards refracture upon removal. With this fixture, the callus does not carry enough load during the healing process because this is done by the very stiff stainless-steel implant. Biodegradable polymers are lightweight materials with a low elastic modulus values ranging from 0.2 to $0.5 \mathrm{GPa}[3,7]$. These materials can be engineered so as to degrade at rates that transmit load to the bone slowly. In addition, complications such as corrosion, release of metal ions and stress protection connected with metal implants are eliminated [3].

An autograft in which the bone tissue is transplanted within the same individual has osteogenic, osteoinductive and/or osteoconductive properties. It contains osteoblasts, stems cells, extracellular matrix, growth factors and cytokines. Autograft osteoblasts determine the osteoid matrix and express osteogenic growth factors. These molecules cause progenitor cells to migrate, proliferate and differentiate into osteoblasts. In a suitable microenvironment, stem cells can split and differentiate towards the osteogenic lineage. The extracellular matrix is used as a cell scaffold. This complex cascade of occurrences ultimately results in bone healing [1].

\section{MATERIALS FOR BONE REGENERATION}

\section{Biocompatible polymers}

Bioresorbable polymers provides various benefits compared to standard alloy originated medical devices. First, due to their radiolucency and the lack of artifacts con- nected with comparable metallic devices subjected to sophisticated diagnostic modalities, bioresorbable based implants enable optimal postoperative radiographic assessment. Owing to their unique biomechanical properties, they can also offer advantages for the fusion healing. Bioresorbable implants gradually reduce stress shielding observed with rigid metallic implant systems, with the elasticity modulus closer to that of the bone and with its gradual resorptive behavior. Flexible and less rigid bioresorbable implants provide the advantage of stabilizing motion segments allowing a greater load transfer to the host spine during implant resorption, potentially minimizing junctional degeneration over the time. While complications such as implant migration, subsidence, and extrusion may still occur with these implants, it clearly becomes less of an issue [8]. Bioresorbable polymers are a good drug carrier. Combining a bioresorbable implant with a medicinal substance such as antibiotics or osteogenic materials creates the possibility of releasing the medicinal substance directly in the treated tissue area. That this may contribute to boost bone healing and formation reducing the postoperative retrieval period $[5,9,10]$.

The desire to compensate for the disadvantages of metallic fixations has culminated in the use of biodegradable polymers in a paradigm shift. The most frequently studied and widely used synthetic biodegradable polymers are polyglycolide/glycolic acid (PGA), polylactide/lactic acid (PLA) and poly- $\varepsilon$-caprolactone (PCL) (Table 1) [3].

Lactide occurs in two stereoisomeric forms: $\mathrm{L}$ or $\mathrm{D}$ $[3,11]$. If the polymer comprises only the L-isomer, it is called poly-L-lactic acid or lactide, PLLA, and, if the polymer consists only of the D-isomer, it is called poly-D-lactic acid or lactide, PDLA. The combination of two isomers is known as poly-D, lactic acid or a lactide (PDLLA) stereo copolymer. The L-isomer occurs in the human body in the metabolism of carbohydrates while the D-isomer is found in acidic milk [3].

For medical applications, natural polymers such as collagen, protein and fibrinogen are also used. Various techniques have been studied for the fabrication of nanostructured biodegradable usable forms, such as foam, film, microspheres and fibers [12-17].

For osteosynthesis, a biodegradable material is more appealing than metals for various reasons. There is no need to remove the material [18]. When applied to a fracture, the ideal bioresorbable implant provides a relatively stable immobilization of bone fragments especially in the direction transverse to the longitudinal axis of the bone. At the same time, as a result of the gradual decrease in the mechanical properties of the implant due to degradation of the bioresorbable polymer structure, its axial stiffness decreases [19]. The gradual reduction of the implant axial stiffness allows for optimal biomechanical conditions for the development of tissue structures in the fracture gap. As a result, it is possible to create callus with mechanical properties ensuring bone fusion in a shorter 
$\mathrm{T}$ a b l e 1. Chemical structure of biodegradable polymers

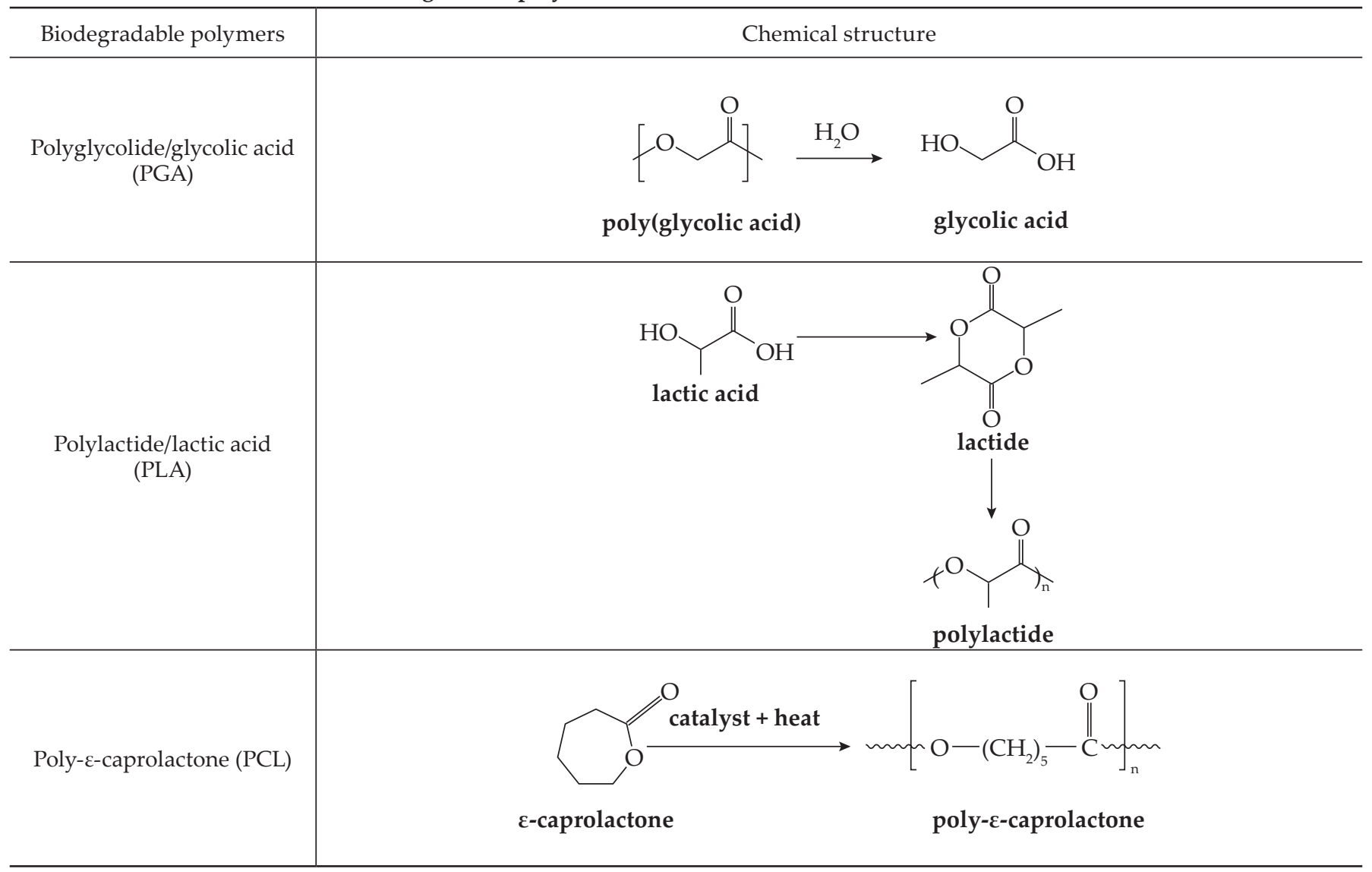

time [20]. Landes et al. stated that due to adequate stabilization, resorbable osteosyntheses effectively improve the stress put on the healing bone by gradual autodegradation [21-23]. After only 3 to 6 months of stable fixation, complete disintegration should not trigger local tissue inflammation [21, 24]. In the case of fractures of the lower limbs, when we are dealing with heavy loads, the Young's modulus of pure polymer may be too low to obtain sufficient rigidity of the fixator. Then you can use a bioresorbable composite consisting of, e.g. PLLA and hydroxyapatite particles (HAp). Such composites based on bioresorbable polymers reinforced with various filler materials are relatively easy to manufacture. In this way it is possible to obtain a two or threefold increase in the value of the material stiffness modulus [25].

Most laboratory and clinical outcomes reveal excellent material biocompatibility and satisfying clinical results. However, a biocompatibility test is required prior to clinical use of newly developed polymers due to evidence of serious foreign-body reactions resulting in osteolysis in the worst case. Schmidmaier et al. [26] examined the biocompatibility of two distinct features of biodegradable membranes. Several techniques, including the use of anti-inflammatory agents, antioxidants, anticoagulants, and fibrinolytics, were researched for adhesion avoidance. However, the most frequently used technique in present surgical studies is absorbable physical obstacles. Above barriers can reduce the formation of the adhesion by limiting tissue apposition during the postsurgical period when adhesions usually occur [27].

\section{Poly(lactic acid)}

Poly(lactic acid) is a bioresorbable polyester which belongs to the group of poly(hydroxy acids). The PLA biodegradation occurs by the non-specific hydrolytic scission of its ester bonds [20]. Polylactide is a bioresorbable $\alpha$-hydroxy ester polymer degraded by hydrolytic scission (mass hydrolysis) at the implant location accompanied by the metabolism in the liver's tricarboxylic acid cycle. When PLA hydrolyzes, it forms lactic acid, a standard muscle contraction substance. Lactic acid is excreted as carbon dioxide and water, being the end products of the poly(lactic acid) degradation [28]. Through hydrolysis, the body degrades PDLLA to lactide acid, completely absorbing by human metabolism. The end products of the PLA degradation are assumed to be removed from the flesh as carbon dioxide and water and - in a tiny part - by urine and feces excretion [18]. Resorption occurs macroscopically in less than a year [28].

Typical tissue reactions against polylactide may include fibroblasts, histocytes, lymphocytes, mast cells, foreign body giant cells, macrophages, plasma cells, eosinophils, and lymphoid cells [29]. It is claimed that the fibrous tissue layer around the implants, usually in the form of the granulation tissue, will gradually decrease with the 
implantation time [29]. The degradation process is still at its beginning in the early phase of bone regeneration. Therefore, the chemical composition (L/DL-lactide) does not impact the amount or the morphology of the regenerate. While applying hollow chamber design results to an almost complete cranial defect filling, the end result can only be evaluated after the completion of the degradation process and complete regenerate remodeling have been achieved by Leiggener et al. [30].

In the case of implants designed for long-term residence in the body, the issue of ensuring adequate functional properties of the implant surface is important. Surface functionalization can be achieved by designing surface topography or by placing bioactive particles on their surface. For bioresorbable polymers such as PLLA, PLGA (polylactic-co-glycolic acid), laser technology is an effective method for preparing surfaces with planned topography. Using appropriate laser processing parameters, it is possible to obtain surfaces with different roughness [31]. Therefore, the implant surface can be structured to achieve the best cell adhesion to the implant surface. A beam of focused light emitted by a $\mathrm{CO}_{2}$ laser can also be used to produce of filigree implants from bioresorbable polymers, such as tissue engineering scaffolds or bioresorbable vascular stents [32]. An important parameter of the implant surface is its wettability. It is well-known that the interaction of proteins with the hydrophobic polymer substance causes the protein denaturation. Generally, hydrophilic surfaces ensure better cell adhesion and, consequently, better tissues integration with the implant. The results of the research show that low-temperature plasma treatment is an effective technique for increasing the wettability of PLLA surfaces [31].

The use of bioactive surfaces may be aimed at achieving an antibacterial effect or the effect of strong biochemical integration of the implant surface with the surrounding tissues. In the first case, surface modification is carried out in order to weaken or completely eliminate the possibility of biofilm formation on the implant surface. This is important in the case of plastic materials which are susceptible to colonization by many bacterial tribes. An example of such solutions are coatings with silver or copper nanoparticles [33].

Many anchorage dependent cells require to adhere to extracellular matrix for their survival and proliferation. Thus the polymer substrates coated with natural Extracellular Matrix (EM) proteins, such as collagen, fibronectin and laminin, have been used for cell culture application. These modifications could be carried out to tailor PLA biomaterial to meet the specific needs of different biomedical applications.

Teixeira et al. [34] reported that PLA scaffolds manufactured by 3D printing and coated with polydopamine and type I collagen considerably increased cell adhesion and the metabolic activity of Mesenchymal Stem Cells (MSC) seeded onto the scaffolds in the early-stage of cell culture.
Haddad et al. [35] stated the successful surface functionalization of poly(lactic acid) (PLA) electrospun nanofibers with amine groups while maintaining the overall mechanical and structural properties of the scaffold. Cell culture studies clearly demonstrated that Epidermal Growth Factors (EGF) enhanced cell viability by maintaining pluripotent cells in a proliferative state.

Zhu et al. [36] reported that chitosan molecules immobilized on the PLA could be modified by heparin (Hp) solution to form a polyelectrolyte complex on the PLA surface. Platelet adhesion assay showed that PLA surface modified by chitosan/heparin complex could inhibit platelet adhesion and activation.

The cited examples show, there are many techniques to design the mechano-biochemical properties of bioresorbable polymers, according to the assumed biofunctionality.

\section{PRECLINICAL STUDIES}

In recent years, several materials have been studied for their use in orthopaedic implants such as polyglycolide (PGA) and copolymers such as poly (glycolide-co-trimethylene carbonate) (PGA-co-TMC), poly(D,L-lactide-co-glycolide) (PDLLA-co-PGA), and poly(L-lactide-co-glycolide) (PLLA-co-PGA); poly(L-lactide) (PLLA), poly(D,L-lactide) (PDLLA), and their copolymers with varying ratios of $\mathrm{L}$ and $\mathrm{D}, \mathrm{L}$ isomers, polydioxanone (PDS), poly(trimethylene carbonate) (PTMC), polyorthoester (POE), poly- $\varepsilon-$ caprolactone (PCL). In addition, composite materials consisting of PLLA/tricalcium phosphate or PLLA/hydroxyapatite have been designed [37].

Poly(glycolic acid), being the first to be widely studied, degrades faster than poly(lactic acid). As a result, polyglycolide showed a higher risk of inflammatory aseptic reaction compared to polylactide. Various compositions of bioresorbable materials change the level of the degradation and the strength of devices. Polylactide was used in the form of both, pure levo and levodextro copolymer. The studies on animals performed by Vaccaro and Madigan found that the combination of its stereoisomers reduces the soft-tissue reaction to the implant [8]. Waris et al. concluded that the most commonly used devices are currently made of poly(L-lactide) (PLLA) or/and copolymers of polylactides $[\mathrm{P}(\mathrm{L} / \mathrm{DL}) \mathrm{LA}]$ and polyglycolide (PLGA) [5].

Absorbable poly(lactic acid) consists in a copolymer of two lactic acid forms (L-lactide and D,L-lactide) [27]. According to Leiggener et al., commercial implants from $70: 30$ poly(L/DL-lactide) are clinically used to fix fractures in low-load regions. Implants made from $80: 20$ poly(L/DL-lactide) are currently under experimental investigation. Higher degree of the crystallinity is resulted in the increase of chemical strength, while loading capacity promises long-term implantation advantages [30]. Gugala and Gogolewski [38] seeded and cultured for 1,2 , and 3 weeks sheep osteoblasts isolated from can- 
cellous bone chips on porous $80 / 20 \%$ poly(L/DL-lactide) scaffolds. Those authors assumed that if the scaffolds supported cell proliferation, they could potentially be used as functional bone graft substitutes after impregnation with autogenous osteoinductive substances or seeding with autogenous osteogenic cells.

During production, the manufacturer can manipulate the strength of the material and its degradation characteristics by using various ratios of the above-mentioned copolymers. Hydrolysis, followed by liver metabolism, degrades the polymer in the body $[27,39]$. Iliopoulos et al. evaluated the formation and development of pericardial and retrosternal adhesions as well as the reduction of the adhesion using two thicknesses $(0.02$ or $0.05 \mathrm{~mm}$ ) of bioresorbable polylactide film [40]. Ultra-fine medicated fibers with non-woven mat diameters varying from several microns to less than $100 \mathrm{~nm}$ can be produced by electrospinning using drug and polymer mixture solution. Since they boast many advantages including improved therapeutic effect, reduced toxicity, convenience and so on, they are predicted to be promising in future biomedical applications, especially in postoperative local chemotherapy $[12,41]$.

Schmidmaier et al. [26] investigated six various treatments: defects without a membrane, defects covered with a poly(D,L-lactide) or with a 70/30 poly(L/D,L-lactide) membrane and all defects with or without spongiosa filling in round cranial defects $(1.5 \mathrm{~cm}$ in diameter) in sheep. According to Gugala and Gogolewski [42], nonand porous membranes from $80 / 20 \%$ poly(L/D,L-lactide) supported the growth and osteoblastic differentiation in rat bone marrow stromal cells in vitro. The porous membrane surface was superior to the non-porous membrane surface. The membranes seeded with stromal cells of bone marrow may accelerate the bone regeneration when used to treat critical-size segmental defects. Ficek and Gogolewski [43] used poly(L/D,L-lactide) beads with a pore size ranged $200-400 \mu \mathrm{m}$ for tendon-to-bone healing in rabbits.

Bozic et al. [20] evaluated crossed K-wires in metacarpal fracture fixation. Landes et al. [44] compared resorbable P(L/DL 70/30)LA plates and screws to titanium miniplates and screws for osteofixation in orthognathic surgery. Those authors concluded that P(L/DL)LA plate-and-screw fixation in orthognathic surgery appears to be as stable as titanium at 1-year follow-up. P(L/DL)LA osteofixations permit minor clinical segment mobility up to 6 weeks post-operatively. P(L/DL)LA provides semirigid fixation that facilitates delayed postoperative occlusal correction and, potentially, condylar positioning [44]. Al-Sukhun et al. [45] showed no abnormal reactions of the foreign body tissue in the magnetic resonance imaging studies in the orbital region. During the critical period of the bone healing, the material showed sufficient strength to stabilize bone segments.

Gugala et al. [46] treated critical segmental defects in sheep tibiae with bioresorbable polylactide membranes: with or without perforations, single or double-tube membrane designs; treated with or without cancellous bone grafting. Defect healing was only found in animals where an autogenous bone graft was used along with the perforated membranes. Compared with historical controls, the presence of perforations strengthened bone graft reconstruction. Double concentrated perforated membranes, i.e. 'tube-in-tube', were more efficient than a single perforated membrane regarding the extent and nature of defect healing. Sołtysiak et al. [47] revealed that those two steps of the manufacturing method (particulate leaching and electrophoretic deposition) lead to the production of porous nanocomposite materials characterized by a biomimetic porous microstructure, required mechanical properties and bioactive behavior. High porosity and pore interconnectivity are essential for ensuring adequate nutrient diffusion through the scaffold, i.e. nutrients to the cells and oxygen transport, and for removing metabolic products [48].

Mueller et al. [49] used two implant systems, which consisted of a burr hole cover, four fixation dowels, a perforated strip and an endocranial membrane. One series was manufactured from $70: 30$ poly(L/DL-lactide), whereas the other from $80: 20$ poly(L/DL-lactide). The thickness of the membranes were achieved $0.3 \mathrm{~mm}$. The neurocranium well-tolerated the biodegradable poly(L/DL-lactide) membranes during the observation period. The dura showed no acute inflammation or marked reaction of the connective tissue. No differences between the two poly types (L/DL-lactide) were detected. The osseous ectopic formation within the dura demonstrates the osteogenic potential of this membrane. The dural bone formation occurs irrespective of whether the dura is in direct contact with the regenerating tissue or is separated from the defect by a polylactide membrane. The dural bone formation displayed no adverse effect, whereas the bone formation was limited. During the observed early stage of the biodegradation, the biocompatibility of both polylactide types was confirmed and no adverse processing residues were reported [49]. Jain et al. [50] suggested that resorbable plates are promising in many aspects of craniofacial surgery and that improvements to their properties may indicated them the gold standard for rigid fixation in the future.

Animal experiments with cylindrical polylactide and titanium mesh implants in the combination with a bone graft for the treatment of critical-size segmental long bone defects show a number of biological and biomechanical advantages. The benefits of the mesh for the reconstruction of segmental bone defects and joint fusion were reported by Gugala et al. [51]. The titanium mesh allows bone graft to be reconstructed uniformly and provides initial mechanical stability for the healing of the defect, without limiting the mass of the patient. The mesh-graft technique comprises a single-stage surgical procedure applies existing implants and does not require specialized surgical skills or equipment. It provides an immedi- 
ate restoration of the osseous continuity, early functional limb recovery, and allows for efficacious defect healing. Treatment approaches that involve the application of cylindrical mesh implants consisting in biodegradable polylactide membranes or titanium cages can incorporate novel osteogenic, osteoinductive, and/or osteoconductive bone healing augmentation materials [51].

Gugala et al. [52] stated that the treatment of non- and microporous poly(L/DL-lactide) membranes with oxygen, ammonia and sulfur dioxide-hydrogen plasmas affects their interaction with rat osteoblasts in culture. The treatment of membranes with oxygen and ammonia plasmas enhances the attachment, growth and activity of rat osteoblasts. Membranes with sulfur dioxide-hydrogen plasma displays negative effects. While the differences in cellular interaction with the membranes treated with oxygen and ammonia the appear subtle, there was a clear trend showing that ammonia plasma was the most effective. Subjecting porous polylactide scaffolds to ammonia plasma may be a means for improving their tissue engineering suitability; still, optimum plasma treatment conditions are yet to be established. Further studies are required to prove whether the treatment of polylactide scaffolds with ammonia plasma has beneficial effects on their performance in vivo [52].

\section{Biodegradation of poly( $\alpha$-hydroxy acid)}

To avoid complications and surgery failure, it is necessary for the complete degradation of a polymer to match the bone-healing time [3]. The rate at which the polymer loses its mechanical strength per time of exposure can be used to assess the rate of load transfer to the bone. The relationship between parameters of the polymer degradation and the blend ratio needs to be investigated for the use of an appropriate polymer in bone surgery [2,3,35]. Generally, it is reasonable to assume that the quicker a material degrades, the earlier the osseous replacement [37].

Gogolewski et al. [29] described the degradation in vivo of polyhydroxy acids-polylactides (PLA), poly(3-hydroxybutyrate) (PHB) and poly(3-hydroxybutyrate-co-3-hydroxyvalerate) (PHB/VA, 5-22\% VA content) as well as the tissue response to these polymers. The study indicated tissues adjacent to the implanted materials. No acute inflammation, abscess formation or tissue necrosis were observed. Additionally, no evident tissue reactivity or cellular mobilization from the implant site were found. Typical tissue responses included mononuclear macrophages, proliferating fibroblasts and mature fibrous capsules. The polymer degradation was followed by an increase in the collagen deposition [29]. The poly $(\alpha-$ -hydroxy acid) biodegradation starts with random hydrolysis of the polymer chains, leading to a decrease in their molecular weight and strength behavior. Polymeric implants are fragmented into smaller particles and finally into oligomers and monomers eliminated by natural metabolic pathways [5].
Landes et al. [21] estimated that the complete PLGA degradation in patients will occur reliably at approximately 12 months, while the $\mathrm{P}(\mathrm{L} / \mathrm{DL}) \mathrm{LA}$ degradation at or before 24 months. These estimates are justified by postoperative reossification observed by dental tomography in the maxillofacial region and the 24-month postoperative inspection in which a lack of the macroscopic implanted material was observed. No difference between interindividual degradation higher than 30 percent was identified. The resorption between screws and plates showed slight variations, probably due to differences in the initial molecular weight or the presence of a residual monomer. The residual low molecular weight fraction content significantly affected the degradation time such as single screw could degrade faster than its counterparts. The results of a four-point bending test in vitro showed 70\% strength retention for PLGA after 75 days and 165 days for the 70:30 P(L/DL)LA implanted material. The materials can be expected to retain their mechanical strength for longer in patients due to the slower degradation of in-patient outcomes [21]. Raghoebar et al. [18] assessed the suitability of screws made of poly(D,L-lactide) acid (PDLLA) to fix autologous bone grafts related to graft regeneration and dental implant osseointegration.

\section{SUMMARY}

Bioresorbable technology offers various advantages compared to standard medical devices made of alloys. Polyhydroxy acids are polymers generally required biocompatibility, irrespective of the shape and location of the implant. Their strength and degradation characteristics can be adjusted during production by varying ratios of these copolymers. They come in the form of non- and porous membranes, screws, plates, mesh and scaffolds. Various shapes and sizes of the described materials allow them to be used for a wide range of the applications. Further research on these materials is needed as the development of biodegradable materials enables their wider use.

\section{ACKNOWLEDGMENTS}

The paper was realized as part of the project "Development of customised biodegradable implants for bone reconstruction procedures", which is carried out under the Operational Programme Smart Growth 2014-2020, agreement no. POIR.01.01.01-00-0646/19-00 with The National Centre for Research and Development, co-financed by the European Regional Development Fund (ERDF).

\section{REFERENCES}

[1] Ip W.Y., Gogolewski S.: Macromolecular Symposia 2007, 253, 139.

http://dx.doi.org/10.1002/masy.200750721

[2] Ginjupalli K., Shavi G.V., Averineni R.K. et al.: Polymer Degradation and Stability 2017, 144, 520.

http://dx.doi.org/10.1016/j.polymdegradstab.2017.08.024 
[3] Adeosun S.O., Lawal G.I., Gbenebor O.P.: Journal of Minerals and Materials Characterization and Engineering 2014, 02 (02), 88.

http://dx.doi.org/10.4236/jmmce.2014.22013

[4] Sheikh Z., Najeeb S., Khurshid Z. et al.: Materials 2015, 8 (9), 5744.

http://dx.doi.org/10.3390/ma8095273

[5] Waris E., Ashammakhi N., Kaarela O. et al.: Journal of Hand Surgery 2004, 29 (6), 590.

http://dx.doi.org/10.1016/j.jhsb.2004.02.005

[6] Seal C.K., Vince K., Hodgson M.A.: IOP Conference Series: Materials Science and Engineering 2009, 4, 012011.

http://dx.doi.org/10.1088/1757-899X/4/1/012011

[7] Gunatillake P.: European Cells and Materials 2003, 5, 1. http://dx.doi.org/10.22203/eCM.v005a01

[8] Robbins M.M., Vaccaro A.R., Madigan L.: Neurosurgical Focus 2008, 16 (3), 1.

http://dx.doi.org/10.3171/foc.2004.16.3.2

[9] Leinonen S., Suokas E., Veiranto M. et al.: The Journal of Craniofacial Surgery 2002, 13 (2), 212. http://dx.doi.org/10.1097/00001665-200203000-00005

[10] Veiranto M., Törmälä P., Suokas E.: Journal of Materials Science: Materials in Medicine 2002, 13, 1259.

[11] Middleton J.C., Tipton A.J.: Biomaterials 2000, 21 (23), 2335. http://dx.doi.org/10.1016/S0142-9612(00)00101-0

[12] Jeun J.P., Kim Y.K., Lim Y.M. et al.: Journal of Industrial and Engineering Chemistry 2007, 13 (4), 592.

[13] King E., Cameron R.E.: Journal of Applied Polymer Science 1997, 66 (9), 1681.

ht t p://dx.doi.org/10.1002/(SICI)10974628(19971128)66:9<1681::AID-APP6>3.0.CO;2-9

[14] Prevo R., Banerji S., Ferguson D.J.P. et al.: Journal of Biological Chemistry 2001, 276 (22), 19420. http://dx.doi.org/10.1074/jbc.M011004200

[15] Zong X.-H., Wang Z.-G., Hsiao B.S. et al.: Macromolecules 1999, 32 (24), 8107. http://dx.doi.org/10.1021/ma990630p

[16] Heald C.R., Stolnik S., Kujawinski K.S. et al.: Langmuir 2002, 18 (9), 3669. http://dx.doi.org/10.1021/la011393y

[17] Shi M., Yang Y.-Y., Chaw C.-S. et al.: Journal of Controlled Release 2003, 89 (2), 167. http://dx.doi.org/10.1016/S0168-3659(02)00493-5

[18] Raghoebar G.M., Liem R.S.B., Bos R.R.M. et al.: Clinical Oral Implants Research 2006, 17 (3), 288. http://dx.doi.org/10.1111/j.1600-0501.2005.01200.x

[19] Bartkowiak-Jowsa M., Będziński R., Kozłowska A. et al.: Meccanica 2013, 48 (3), 721. http://dx.doi.org/10.1007/s11012-012-9626-2

[20] Bozic K.J., Perez L.E., Wilson D.R. et al.: Journal of Hand Surgery 2001, 26 (4), 755. http://dx.doi.org/10.1053/jhsu.2001.24145

[21] Landes C.A., Ballon A., Roth C.: Journal of Biomedical Materials Research Part B: Applied Biomaterials 2006, 76 (2), 403. http://dx.doi.org/10.1002/jbm.b.30388

[22] Rubin J.P., Yaremchuk M.J.: Plastic and Reconstructive Surgery 1997, 100 (5), 1336.

http://dx.doi.org/10.1097/00006534-199710000-00043

[23] Pietrzak W.S., Eppley B.L.: The Journal of Craniofacial Surgery 2000, 11 (6), 575.

http://dx.doi.org/10.1097/00001665-200011060-00011

[24] Wiltfang J., Merten H.A., Schultze-Mosgau S. et al.: The Journal of Craniofacial Surgery 2000, 11 (3), 239. http://dx.doi.org/10.1097/00001665-200011030-00006

[25] Bartkowiak-Jowsa M., Kwiatkowska A., Będziński R. et al.: Journal of Composite Materials 2014, 48 (7), 815. http://dx.doi.org/10.1177/0021998313477897

[26] Schmidmaier G., Baehr K., Mohr S. et al.: Clinical Oral Implants Research 2006, 17 (4), 439. http://dx.doi.org/10.1111/j.1600-0501.2005.01242.x

[27] Avital S., Bollinger T.J., Wilkinson J.D. et al.: Diseases of the Colon and Rectum 2005, 48 (1), 153. http://dx.doi.org/10.1007/s10350-004-0748-z

[28] Walsh W.R., Evans R.O.N., Iliopoulos J. et al.: Journal of Biomedical Materials Research Part B: Applied Biomaterials 2006, 79 (1), 166. http://dx.doi.org/10.1002/jbm.b.30527

[29] Gogolewski S., Jovanovic M., Perren S.M. et al.: Journal of Biomedical Materials Research 1993, 27 (9), 1135.

[30] Leiggener C.S., Curtis R., Müller A.A. et al.: Biomaterials 2006, 27 (2), 202. http://dx.doi.org/10.1016/j.biomaterials.2005.05.068

[31] Kobielarz M., Gazińska M., Tomanik M. et al.: Polymer Degradation and Stability 2019, 165, 182.

http://dx.doi.org/10.1016/j.polymdegradstab.2019.05.010

[32] Stępak B., Antończak A.J., Bartkowiak-Jowsa M. et al.: Archives of Civil and Mechanical Engineering 2014, 14 (2), 317. http://dx.doi.org/10.1016/j.acme.2013.08.005

[33] Laput O., Vasenina I., Salvadori M.C. et al.: Journal of Materials Science 2019, 54 (17), 11726. http://dx.doi.org/10.1007/s10853-019-03693-4

[34] Teixeira B.N., Aprile P., Mendonça R.H. et al.: Journal of Biomedical Materials Research Part B: Applied Biomaterials 2019, 107 (1), 37. http://dx.doi.org/10.1002/jbm.b.34093

[35] Haddad T., Noel S., Liberelle B. et al.: Biomatter 2016, 6 (1), e1 231276. http://dx.doi.org/10.1080/21592535.2016.1231276

[36] Zhu A., Zhang M., Wu J., Shen J.: Biomaterials 2002, 23 (23), 4657. http://dx.doi.org/10.1016/S0142-9612(02)00215-6

[37] Weiler A., Hoffmann R.F.G., Stähelin A.C. et al.: Arthroscopy 2000, 16 (3), 305. http://dx.doi.org/10.1016/S0749-8063(00)90055-0

[38] Gugala Z., Gogolewski S.: Journal of Biomedical Materials Research Part A 2005, 75A (3), 702. http://dx.doi.org/10.1002/jbm.a.30479

[39] Claes L.E., Ignatius A.A., Rehm K.E., Scholz C.: Biomaterials 1996, 17 (16), 1621. 
http://dx.doi.org/10.1016/0142-9612(95)00327-4

[40] Iliopoulos J., Cornwall G.B., Evans R.O.N. et al.: Journal of Surgical Research 2004, 118 (2), 144. http://dx.doi.org/10.1016/j.jss.2003.10.023

[41] Reneker D.H., Chun I.: Nanotechnology 1996, 7 (3), 216.

[42] Gugala Z., Gogolewski S.: Biomaterials 2004, 25 (12), 2299. http://dx.doi.org/10.1016/j.biomaterials.2003.09.009

[43] Ficek K., Gogolewski S.: ORS Annual Meeting 2010, 271, paper No. 0271.

[44] Landes C.A., Ballon A.: Plastic and Reconstructive Surgery 2006, 118 (3), 703. http://dx.doi.org/10.1097/01.prs.0000232985.05153.bf

[45] Al-Sukhun J., Törnwall J., Lindqvist C., Kontio R.: Journal of Oral and Maxillofacial Surgery 2006, 64 (1), 47. http://dx.doi.org/10.1016/j.joms.2005.09.013

[46] Gugala Z., Gogolewski S.: Injury 2002, 33, 71.
[47] Sołtysiak E., Długoń E., Dulnik J., Błażewicz M.: Przetwórstwo Tworzyw 2011, 6, 511.

[48] Stodolak-Zych E., Frączek-Szczypta A., Wiecheć A., Błażewicz M.: Acta Physica Polonica A 2012, 121 (2), 518.

[49] Mueller A.A., Rahn B.A., Gogolewski S., Leiggener C.S.: Pediatric Neurosurgery 2005, 41 (6), 285. http://dx.doi.org/10.1159/000088730

[50] Jain S.A., Simmons O.P., Hanemann M.S. et al.: Archives of Facial Plastic Surgery 2006, 8 (6), 390. http://dx.doi.org/10.1001/archfaci.8.6.390

[51] Gugala Z., Lindsey R.W., Gogolewski S.: Macromolecular Symposia 2007, 253, 147. http://dx.doi.org/10.1002/masy.200750722

[52] Gugala Z., Gogolewski S.: Journal of Biomedical Materials Research Part A 2006, 76 (2), 288. http://dx.doi.org/10.1002/jbm.a.30462

Received 25 V 2020

\section{W kolejnym zeszycie ukażą się m.in. następujące artykuły:}

N.M. Nurazzi, M.M. Harussani, N.D. Siti Zulaikha, A.H. Norhana, M. Imran Syakir, A. Norli - Kompozyty na bazie przewodzącego polimeru z udziałem nanorurek węglowych w czujnikach gazu DMMP - przegląd literatury (j. ang.)

P. Ravikumar, S. Sagadevan - Wpływ dodatku nanokrystalicznej chityny na właściwości folii z octanu celulozy (j. ang.)

I.P. Mahendra, P.T. Nghia, N.T.H. Phuong, T.T. Hang, N.F. Alias, H. Ismail - Mieszaniny poli(kwas L-mlekowy)/ zdeprotonowany kauczuk naturalny o zwiększonej kompatybilności (j. ang.)

L. Song, Z. Li, L. Yang, N. Wang, J. Zhao, Z. Gu - Otrzymywanie i charakterystyka mikrokapsułek attapulgitu powlekanych polimerami akrylowymi (j. ang.)

M. Zulham Efendi Sinaga, S. Gea, C.F. Zuhra, Y.A. Sihombing, E. Zaidar, F. Sebayang, T.U. Ningsih - Wpływ zawartości plastyfikatorów i chitozanu na strukturę i właściwości cienkich folii do pakowania żywności na bazie Gracilaria sp. (j. ang.)

A. Baeza-Campuzano, V.M. Castaño - Wpływ prędkości drukowania na temperaturę i zachowanie nici polimerowej na wyjściu z dyszy drukarki 3D (j. ang.) 